\title{
Effects of Calcium on the Alleviation of Cadmium Toxicity in Salix matsudana and Its Effects on Other Minerals
}

\author{
Xiaoshuo Shang, Wenxiu Xue, Yi Jiang, Jinhua Zou* \\ Tianjin Key Laboratory of Animal and Plant Resistance, College of Life Science, \\ Tianjin Normal University, Tianjin 300387, China
}

Received: 30 March 2019

Accepted: 29 May 2019

\begin{abstract}
Effects of exogenous calcium $(5 \mathrm{mmol} / \mathrm{L})$ on accumulation of manganese, iron, copper and zinc in different organs (roots, new stems, leaves and old stems) of Salix matsudana Koidz exposed to 10 and $50 \mu \mathrm{mol} / \mathrm{L}$ cadmium for 7, 14, 21 and $28 \mathrm{~d}$ were investigated in order to further understand calcium effects in alleviating cadmium toxicity. The results showed that cadmium could inhibit seedling growth of $S$. matsudana. $5 \mathrm{mmol} / \mathrm{L}$ calcium had a alleviating toxic effects on seedling growth. Results indicated that cadmium contents in the different organs increased significantly $(P<0.05)$ with increasing cadmium concentration and prolonged duration of treatment. Cadmium concentrated mainly in the roots, and small amounts were transferred to shoots. $5 \mathrm{mmol} / \mathrm{L}$ calcium decreased the cadmium levels significantly $(P<0.05)$ in the organs of $S$. matsudana exposed to all the cadmium concentrations used during the whole experiment. Data revealed that cadmium stress mainly affected the accumulation of manganese both in roots and shoots. Cadmium could induce the high levels of iron, zinc and copper in roots. Data also indicated that exogenous calcium could promote the absorption of copper, iron, zinc and manganese to different extent, suggesting that calcium has the alleviating effect on the toxicity of cadmium.
\end{abstract}

Keywords: cadmium $(\mathrm{Cd})$, calcium(Ca), minerals, Salix matsudana Koidz

\section{Introduction}

Cadmium $(\mathrm{Cd})$ is a highly toxic trace element mainly derived from industrial processes and phosphate fertilizers [1]. Cd concentrations in soil near smelters are extremely high, up to $200 \mathrm{mg} / \mathrm{kg}$ [2]. Considerable attention has been attached to problems associated with

*e-mail: zjhmon@126.com
Cd pollution, with the development of modern industry and agriculture. It is a non-essential heavy metal with high toxicity to plants, animals and humans [3] and has been regarded as most dangerous environmental pollutant [4]. $\mathrm{Cd}$ is of great concern because it is a nonessential toxic element which has toxic effects on plants, animals and humans with a very small dose [5]. Under Cd stress, growth and development of plants are affected, such as inhibiting photosynthesis and respiration, disturbing the normal division of root tip cells, and causing imbalances in nutrition 
[6-11]. Therefore, remediation of Cd pollution in the environment to avoid its threats is very important and urgently needed [5].

Some heavy metals (HMs), such as copper $(\mathrm{Cu})$, zinc $(\mathrm{Zn})$, iron $(\mathrm{Fe})$, manganese $(\mathrm{Mn})$, are required for the normal growth, development, and reproduction of plants [12]. Cd interferes with the uptake, transport, and use of different macro- and micronutrients. Microelements $\mathrm{Zn}, \mathrm{Fe}, \mathrm{Mn}$, and $\mathrm{Cu}$ interfering with $\mathrm{Cd}$ uptake may decrease $\mathrm{Cd}$ concentrations in plants [13]. Calcium (Ca) is known as a necessary nutrient for plant growth and development. As the second messenger $\mathrm{Ca}$ can couple extracellular signals with intracellular physiological and biochemical reactions, enhancing plant resistance to environmental stress by stabilizing cell wall, cell membrane structure and inducing expression of specific genes $[14,15]$. It was reported that exogenous $\mathrm{Ca}$ is an important signaling messenger and essential nutrient element and plays an important role in many adaptation and development processes of plant cells [16].

Salix matsudana Koidz (Chinese willow) grows in a wide range of climatic conditions and is one of the most widely cultivated willow species in China [17]. It is a fast-growing, productive, and deeply rooted tree of the willow species that adapts to temperate region climatic conditions and has the ability to tolerate high Cd $[18,19]$. These traits make it a potential ideal candidate for phytoremediation of Cd-contaminated waters and soils $[18,20]$. Some research works were reported to be involved in $\mathrm{Cd}$ stress on mineral uptake and accumulation in S. matsudana [7, 20, 21]. However, the research on the effects of $\mathrm{Ca}$ on other metal accumulation and translocation in S. matsudana under $\mathrm{Cd}$ stress remains unknown. How $\mathrm{Ca}$ helps to alleviate the $\mathrm{Cd}$-induced toxicity requires more investigations. Therefore, S. matsudana was used to explore the alleviating effect of $\mathrm{Ca}$ and its specific function during the uptake and accumulation of $\mathrm{Cd}$ and other minerals $(\mathrm{Cu}, \mathrm{Zn}, \mathrm{Mn}$ and $\mathrm{Fe})$ in roots and shoots of S. matsudana in the present investigation.

\section{Experimental}

\section{Seedlings Cultivation and Treatment}

Woody cuttings (15 cm long) from one-year-old shoots of $S$. matsudana grown in the campus of Tianjin Normal University, China were collected and rooted in plastic buckets filled with distilled water for two weeks under glasshouse conditions of $23 \pm 5^{\circ} \mathrm{C}$ and $55 \pm 10 \%$ relative humidity before starting the experiments. After the seedlings burgeoned, healthy (without leaf chlorotic spots and withered) and uniform (similar height) plants were transferred and cultivated to $1 / 2$ Hoagland nutrient solution for 7, 14, 21 and $28 \mathrm{~d}$. $\mathrm{Cd}$ and $\mathrm{Ca}$ were added to the containers to form five treatments: basal nutrient solution (control, without $\mathrm{Cd}$ and $\mathrm{Ca}$ ), $10 \mu \mathrm{mol} / \mathrm{L}$ $\mathrm{Cd}, 10 \mu \mathrm{mol} / \mathrm{L} \mathrm{Cd}$ and $5 \mathrm{mmol} / \mathrm{L} \mathrm{Ca}, 50 \mu \mathrm{mol} / \mathrm{L} \mathrm{Cd}$,

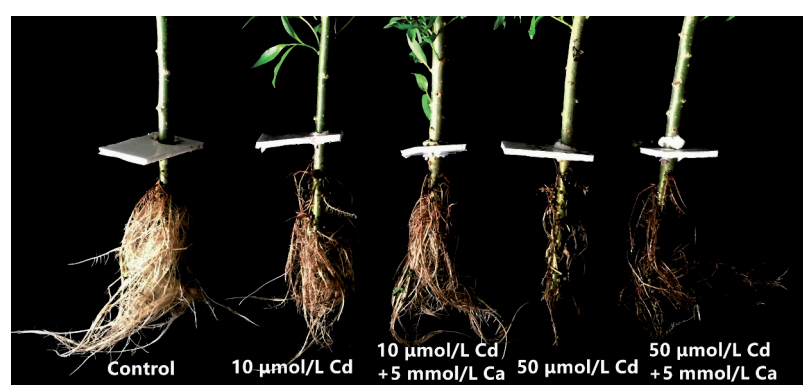

Fig. 1 Effect of exogenous $\mathrm{Ca}$ on the growth of S. matsudana under Cd stress (28d).

$50 \mu \mathrm{mol} / \mathrm{L} \mathrm{Cd}$ and $5 \mathrm{mmol} / \mathrm{L} \mathrm{Ca}$. The nutrient solution consisted of $5 \mathrm{mmol} / \mathrm{L} \mathrm{KNO}_{3}, 5 \mathrm{mmol} / \mathrm{L} \mathrm{Ca}\left(\mathrm{NO}_{3}\right)_{2}$, $1 \mu \mathrm{mmol} / \mathrm{L} \quad \mathrm{KH}_{2} \mathrm{PO}_{4}, 50 \mu \mathrm{mol} / \mathrm{L} \quad \mathrm{H}_{3} \mathrm{BO}_{3}, 10 \mu \mathrm{mol} / \mathrm{L}$ FeEDTA, $4.5 \mu \mathrm{mol} / \mathrm{L} \quad \mathrm{MnCl}_{2}, 3.8 \mu \mathrm{mol} / \mathrm{L} \quad \mathrm{ZnSO}_{4}$, $0.3 \mu \mathrm{mol} / \mathrm{L} \mathrm{CuSO}_{4}$, and $0.1 \mu \mathrm{mol} / \mathrm{L}\left(\mathrm{NH}_{4}\right)_{6} \mathrm{Mo}_{7} \mathrm{O}_{24}$,

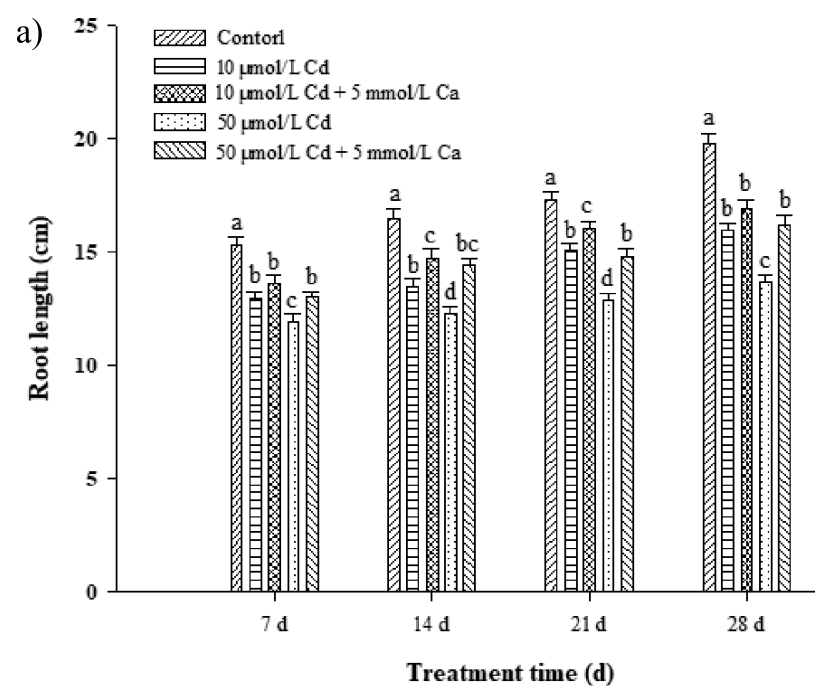

b)

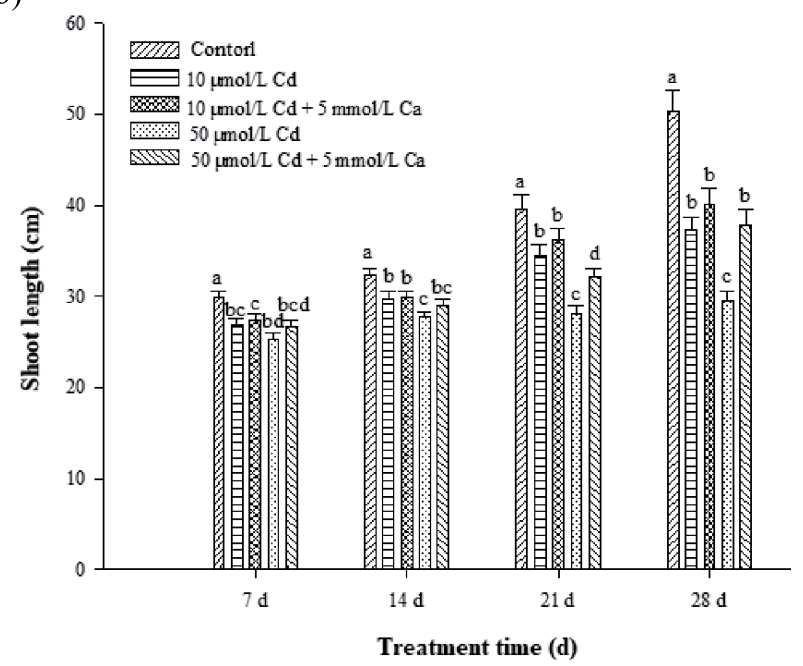

Fig. 2 Effect of exogenous $\mathrm{Ca}$ on plant height and root length of S. matsudana under Cd stress.

Values followed by different letters differ significantly from each other $(P<0.05, t$-test $)$. Means \pm SE, $\mathrm{n}=5$. 
Table 1. Effect of exogenous Ca on Cd content in different organs of S. matsudana under different concentrations of Cd sress.

\begin{tabular}{|c|c|c|c|c|c|}
\hline \multirow{2}{*}{$\begin{array}{l}\text { Time } \\
\text { (d) }\end{array}$} & \multirow{2}{*}{$\begin{array}{c}\text { Treatment } \\
\mathrm{Cd}(\mu \mathrm{mol} / \mathrm{L}) \\
\mathrm{Ca}(\mathrm{mmol} / \mathrm{L})\end{array}$} & \multicolumn{4}{|c|}{$\mathrm{Cd}(\mu \mathrm{g} / \mathrm{g}, \mathrm{DW} \pm \mathrm{SE})$} \\
\hline & & Root & New stem & Leaf & Old stem \\
\hline \multirow{5}{*}{7} & 0 & $4.70 \pm 0.46 \mathrm{a}$ & $4.85 \pm 0.01 \mathrm{a}$ & $5.86 \pm 0.01 \mathrm{a}$ & $1.19 \pm 0.01 \mathrm{a}$ \\
\hline & $10 \mathrm{Cd}$ & $584.55 \pm 1.58 \mathrm{~b}$ & $68.54 \pm 0.22 b$ & $58.27 \pm 0.12 b$ & $6.98 \pm 0.07 \mathrm{~b}$ \\
\hline & $10 \mathrm{Cd}+5 \mathrm{Ca}$ & $571.57 \pm 2.32 \mathrm{c}$ & $36.80 \pm 0.09 \mathrm{c}$ & $22.38 \pm 0.07 \mathrm{c}$ & $2.68 \pm 0.01 \mathrm{c}$ \\
\hline & $50 \mathrm{Cd}$ & $2041.95 \pm 4.04 \mathrm{~d}$ & $71.35 \pm 0.23 d$ & $23.54 \pm 0.03 \mathrm{~d}$ & $9.38 \pm 0.01 \mathrm{~d}$ \\
\hline & $50 \mathrm{Cd}+5 \mathrm{Ca}$ & $963.50 \pm 6.74 \mathrm{e}$ & $63.36 \pm 1.92 b$ & $47.81 \pm 0.32 \mathrm{~b}$ & $5.08 \pm 0.02 \mathrm{e}$ \\
\hline \multirow{5}{*}{14} & 0 & $4.97 \pm 0.01 \mathrm{a}$ & $5.67 \pm 0.08 \mathrm{a}$ & $6.27 \pm 0.01 \mathrm{a}$ & $1.28 \pm 0.04 \mathrm{a}$ \\
\hline & $10 \mathrm{Cd}$ & $1021.37 \pm 1.56 b$ & $70.13 \pm 0.10 b$ & $57.22 \pm 0.73 b$ & $8.38 \pm 0.02 b$ \\
\hline & $10 \mathrm{Cd}+5 \mathrm{Ca}$ & $879.55 \pm 5.57 \mathrm{c}$ & $40.38 \pm 1.21 \mathrm{c}$ & $27.99 \pm 0.02 \mathrm{c}$ & $4.98 \pm 0.02 \mathrm{c}$ \\
\hline & $50 \mathrm{Cd}$ & $2563.91 \pm 0.85 \mathrm{~d}$ & $151.57 \pm 2.45 \mathrm{~d}$ & $103.83 \pm 0.03 \mathrm{~d}$ & $17.57 \pm 0.05 \mathrm{~d}$ \\
\hline & $50 \mathrm{Cd}+5 \mathrm{Ca}$ & $1329.55 \pm 1.24 \mathrm{e}$ & $121.89 \pm 0.71 \mathrm{e}$ & $83.24 \pm 2.52 \mathrm{e}$ & $14.77 \pm 0.06 \mathrm{e}$ \\
\hline \multirow{5}{*}{21} & 0 & $5.00 \pm 0.02 \mathrm{a}$ & $5.76 \pm 0.04 \mathrm{a}$ & $6.93 \pm 0.02 \mathrm{a}$ & $1.30 \pm 0.01 \mathrm{a}$ \\
\hline & $10 \mathrm{Cd}$ & $1360.18 \pm 1.62 b$ & $112.16 \pm 1.39 \mathrm{~b}$ & $134.88 \pm 0.35 b$ & $15.22 \pm 0.07 \mathrm{~b}$ \\
\hline & $10 \mathrm{Cd}+5 \mathrm{Ca}$ & $1071.39 \pm 31.06 \mathrm{c}$ & $52.45 \pm 0.08 \mathrm{c}$ & $62.10 \pm 0.20 c$ & $6.46 \pm 0.06 \mathrm{c}$ \\
\hline & $50 \mathrm{Cd}$ & $2982.71 \pm 1.38 \mathrm{~d}$ & $171.16 \pm 0.53 \mathrm{~d}$ & $167.46 \pm 0.06 \mathrm{~d}$ & $25.74 \pm 0.09 \mathrm{~d}$ \\
\hline & $50 \mathrm{Cd}+5 \mathrm{Ca}$ & $2073.87 \pm 3.73 \mathrm{e}$ & $145.01 \pm 0.31 \mathrm{e}$ & $149.85 \pm 0.49 \mathrm{e}$ & $20.93 \pm 0.56 \mathrm{e}$ \\
\hline \multirow{5}{*}{28} & 0 & $5.89 \pm 0.01 \mathrm{a}$ & $5.81 \pm 0.01 \mathrm{a}$ & $7.11 \pm 0.00 \mathrm{a}$ & $1.48 \pm 0.07 \mathrm{a}$ \\
\hline & $10 \mathrm{Cd}$ & $1365.4 \pm 0.44 b$ & $105.46 \pm 1.75 b$ & $174.93 \pm 0.21 b$ & $28.04 \pm 0.01 \mathrm{~b}$ \\
\hline & $10 \mathrm{Cd}+5 \mathrm{Ca}$ & $1327.20 \pm 0.22 \mathrm{c}$ & $97.83 \pm 0.08 \mathrm{c}$ & $124.68 \pm 2.29 \mathrm{c}$ & $20.9 \pm 1.22 \mathrm{c}$ \\
\hline & $50 \mathrm{Cd}$ & $3422.11 \pm 3.59 \mathrm{~d}$ & $223 \pm 0.57 \mathrm{~d}$ & $188.24 \pm 1.44 \mathrm{~d}$ & $56.74 \pm 0.08 \mathrm{~d}$ \\
\hline & $50 \mathrm{Cd}+5 \mathrm{Ca}$ & $3234.00 \pm 1.17 \mathrm{e}$ & $206.89 \pm 0.42 \mathrm{e}$ & $166.54 \pm 0.57 \mathrm{e}$ & $41.53 \pm 1.08 \mathrm{e}$ \\
\hline
\end{tabular}

Values followed by different letters differ significantly from each other $(P<0.05, t$-test $)$. Means $\pm \mathrm{SE}, \mathrm{n}=3$.

adjusted to $\mathrm{pH}$ 5.5. Cd was provided as cadmium chloride $\left(\mathrm{CdCl}_{2} \times 2.5 \mathrm{H}_{2} \mathrm{O}\right)$. Cadmium stock solution was prepared in deionized water. $\mathrm{Ca}$ was provided as calcium chloride $\left(\mathrm{CaCl}_{2}\right)$. The nutrient solutions were renewed once every $7 \mathrm{~d}$, and the air pump was used for ventilation during the culture. All treatments were performed in three replicates.

\section{Determination of $\mathrm{Cd}$ and Other Minerals}

Roots and shoots from each treatment were harvested from the cuttings at each time interval (7 d). After removal of necrotic and putrid tissue, the shoots were washed thoroughly with running tap water for 30 min and then with deionized water to remove traces of nutrients, $\mathrm{Cd}$ and $\mathrm{Ca}$ ions from seedling surfaces. The plants were divided root, leaf, new stem and old stem. The samples were dried for $3 \mathrm{~d}$ at $45^{\circ} \mathrm{C}, 1 \mathrm{~d}$ at $80^{\circ} \mathrm{C}$, and $12 \mathrm{~h}$ at constant $105^{\circ} \mathrm{C}$ in an oven. All dried plant samples were prepared using wet-digestion methods. The contents of $\mathrm{Cd}, \mathrm{Fe}, \mathrm{Mn}, \mathrm{Cu}$ and $\mathrm{Zn}$ were analyzed using inductively coupled plasma atomic emission spectrometry (ICP-AES) (Leeman Labs Inc., USA).

\section{Statistical Analysis}

All statistical values were calculated using the Statistical Package for Social Sciences (SPSS) program release 17.0 for Windows (SPSS, Chicago, IL, USA) and Sigma Plot 12.5 using means \pm standard error (SE). For equality of averages the $t$-test was applied. Results were considered statistically significant at $P<0.05$.

\section{Results}

\section{Effects of Exogenous $\mathrm{Ca}$ on the Growth} of $S$. matsudana under Cd Stress

\section{Effects of Cd on Root and Shoot Growth}

The effects of $\mathrm{Cd}$ on root growth of S. matsudana varied with the concentration and duration of treatment (Figs 1 and 2). 10 and $50 \mu \mathrm{mol} / \mathrm{L} \mathrm{Cd}$ exposure had toxic effect on root growth and the shoot length was inhibited significantly with increasing treatment time when compared to control $(P<0.05)$. The shoot growth treated 
Table 2. Effect of exogenous Ca on Mn content in different organs of S. matsudana under different concentrations of Cd sress.

\begin{tabular}{|c|c|c|c|c|c|}
\hline \multirow{2}{*}{$\begin{array}{l}\text { Time } \\
\text { (d) }\end{array}$} & \multirow{2}{*}{$\begin{array}{c}\text { Treatment } \\
\mathrm{Cd}(\mu \mathrm{mol} / \mathrm{L}) \\
\mathrm{Ca}(\mathrm{mmol} / \mathrm{L})\end{array}$} & \multicolumn{4}{|c|}{$\mathrm{Mn}(\mu \mathrm{g} / \mathrm{g}, \mathrm{DW} \pm \mathrm{SE})$} \\
\hline & & Root & New stem & Leaf & Old stem \\
\hline \multirow{5}{*}{7} & 0 & $67.22 \pm 0.01 \mathrm{a}$ & $14.48 \pm 0.01 \mathrm{a}$ & $74.14 \pm 0.20 \mathrm{a}$ & $4.19 \pm 0.01 \mathrm{a}$ \\
\hline & $10 \mathrm{Cd}$ & $32.28 \pm 0.12 b$ & $9.39 \pm 0.04 \mathrm{~b}$ & $70.93 \pm 0.08 b$ & $2.18 \pm 0.03 b$ \\
\hline & $10 \mathrm{Cd}+5 \mathrm{Ca}$ & $21.29 \pm 0.19 \mathrm{c}$ & $10.64 \pm 0.03 \mathrm{c}$ & $77.18 \pm 0.25 \mathrm{c}$ & $3.35 \pm 0.01 \mathrm{c}$ \\
\hline & $50 \mathrm{Cd}$ & $28.50 \pm 0.03 \mathrm{~d}$ & $11.06 \pm 0.05 \mathrm{c}$ & $65.16 \pm 0.08 \mathrm{~d}$ & $3.15 \pm 0.02 \mathrm{~d}$ \\
\hline & $50 \mathrm{Cd}+5 \mathrm{Ca}$ & $45.64 \pm 0.11 \mathrm{e}$ & $13.39 \pm 0.23 \mathrm{~d}$ & $68.94 \pm 0.36 \mathrm{e}$ & $4.02 \pm 0.02 \mathrm{e}$ \\
\hline \multirow{5}{*}{14} & 0 & $150.57 \pm 0.21 \mathrm{a}$ & $15.67 \pm 0.16 \mathrm{a}$ & $79.69 \pm 0.15 \mathrm{a}$ & $4.27 \pm 0.08 \mathrm{a}$ \\
\hline & $10 \mathrm{Cd}$ & $51.03 \pm 0.03 b$ & $8.4 \pm 0.02 b$ & $68.05 \pm 0.23 b$ & $2.96 \pm 0.01 \mathrm{~b}$ \\
\hline & $10 \mathrm{Cd}+5 \mathrm{Ca}$ & $30.89 \pm 0.22 \mathrm{c}$ & $8.81 \pm 0.30 \mathrm{~b}$ & $72.25 \pm 0.06 \mathrm{c}$ & $3.61 \pm 0.01 \mathrm{c}$ \\
\hline & $50 \mathrm{Cd}$ & $17.57 \pm 0.01 \mathrm{~d}$ & $10.59 \pm 0.03 \mathrm{c}$ & $60.62 \pm 0.03 \mathrm{~d}$ & $3.11 \pm 0.01 \mathrm{~b}$ \\
\hline & $50 \mathrm{Cd}+5 \mathrm{Ca}$ & $39.69 \pm 0.05 \mathrm{e}$ & $12.54 \pm 0.25 \mathrm{~d}$ & $65.86 \pm 0.17 \mathrm{e}$ & $4.57 \pm 0.40 \mathrm{a}$ \\
\hline \multirow{5}{*}{21} & 0 & $152.33 \pm 0.26 \mathrm{a}$ & $16.80 \pm 0.03 \mathrm{a}$ & $89.12 \pm 0.12 \mathrm{a}$ & $4.78 \pm 0.01 \mathrm{a}$ \\
\hline & $10 \mathrm{Cd}$ & $63.19 \pm 0.15 b$ & $6.8 \pm 0.06 \mathrm{~b}$ & $60.80 \pm 0.24 b$ & $3.15 \pm 0.01 \mathrm{~b}$ \\
\hline & $10 \mathrm{Cd}+5 \mathrm{Ca}$ & $44.66 \pm 0.17 \mathrm{c}$ & $7.94 \pm 0.02 \mathrm{c}$ & $67.34 \pm 0.12 \mathrm{c}$ & $3.95 \pm 0.04 \mathrm{c}$ \\
\hline & $50 \mathrm{Cd}$ & $14.23 \pm 0.01 \mathrm{~d}$ & $8.15 \pm 0.03 c$ & $55.96 \pm 0.07 \mathrm{~d}$ & $3.41 \pm 0.02 \mathrm{~d}$ \\
\hline & $50 \mathrm{Cd}+5 \mathrm{Ca}$ & $24.24 \pm 0.03 \mathrm{e}$ & $9.83 \pm 0.21 \mathrm{~d}$ & $58.94 \pm 0.22 \mathrm{e}$ & $4.71 \pm 0.11 \mathrm{a}$ \\
\hline \multirow{5}{*}{28} & 0 & $239.28 \pm 0.19 a$ & $17.38 \pm 0.01 \mathrm{a}$ & $90.34 \pm 0.39 a$ & $4.84 \pm 0.21 \mathrm{a}$ \\
\hline & $10 \mathrm{Cd}$ & $90.01 \pm 0.11 \mathrm{~b}$ & $6.16 \pm 0.11 b$ & $57.98 \pm 0.01 \mathrm{~b}$ & $3.35 \pm 0.02 b$ \\
\hline & $10 \mathrm{Cd}+5 \mathrm{Ca}$ & $53.1 \pm 0.15 \mathrm{c}$ & $6.70 \pm 0.02 \mathrm{c}$ & $63.04 \pm 0.16 \mathrm{c}$ & $4.38 \pm 0.16 \mathrm{c}$ \\
\hline & $50 \mathrm{Cd}$ & $12.95 \pm 0.01 \mathrm{~d}$ & $7.42 \pm 0.08 \mathrm{~d}$ & $49.25 \pm 0.24 d$ & $3.56 \pm 0.01 \mathrm{~b}$ \\
\hline & $50 \mathrm{Cd}+5 \mathrm{Ca}$ & $20.28 \pm 0.05 \mathrm{e}$ & $8.55 \pm 0.02 \mathrm{e}$ & $56.79 \pm 0.11 \mathrm{e}$ & $4.89 \pm 0.15 \mathrm{a}$ \\
\hline
\end{tabular}

Values followed by different letters differ significantly from each other $(P<0.05, t$-test $)$. Means $\pm \mathrm{SE}, \mathrm{n}=3$.

with 10 and $50 \mu \mathrm{mol} / \mathrm{L} \mathrm{Cd}$ showed the same growth trend as control. The effects of $\mathrm{Cd}$ on the morphology of the roots of $S$. matsudana exposed to 10 and $50 \mu \mathrm{mol} / \mathrm{L}$ Cd showed to be dark brown in colour when compared with control after Cd treatment for $28 \mathrm{~d}$.

\section{Effects of Exogenous Ca on Root and Shoot Growth under Cd Stress}

The effect of $\mathrm{Ca}$ on root growth of S. matsudana exposed to $\mathrm{Cd}$ varied with the concentration and duration of treatment (Fig. 1). $5 \mathrm{mmol} / \mathrm{L} \mathrm{Ca}$ had the alleviating toxic effects of $\mathrm{Cd}$ on root growth induced by $\mathrm{Cd}$ significantly $(P<0.05)$ in comparison with the groups exposed to 10 and $50 \mu \mathrm{mol} / \mathrm{L} \mathrm{Cd}$ during the whole experiment, except for the group treated with $10 \mu \mathrm{mol} / \mathrm{L} \mathrm{Cd}$ for $7 \mathrm{~d}$. As for shoot length, $5 \mathrm{mmol} / \mathrm{L}$ $\mathrm{Ca}$ also had alleviating toxic effects significantly $(P<0.05)$ on shoot length treated with $50 \mu \mathrm{mol} / \mathrm{L} \mathrm{Cd}$ for 21 and $28 \mathrm{~d}$.

\section{Effects of Exogenous $\mathrm{Ca}$ on $\mathrm{Cd}$ Accumulation and Other Minerals}

\section{Cd Content}

Cd uptake and accumulation in the different organs of S. matsudana varied depending on Cd concentration and treatment time. Data showed that the $\mathrm{Cd}$ contents in roots exposed to 10 and $50 \mu \mathrm{mol} / \mathrm{L} \mathrm{Cd}$ increased significantly $(P<0.05)$ with increasing $\mathrm{Cd}$ concentration and prolonged duration of treatment when compared to control (Table 1). The Cd contents in new stem, leaf and old stem of $S$. matsudana had the same trend as roots. The levels of $\mathrm{Cd}$ in the different organs of S. matsudana were in the order as follows: root $>$ new stem $>$ leaf $>$ old stem during $14 \mathrm{~d}$ treatment period. Cd concentrated mainly in the roots, and small amounts were transferred to shoots. Data here indicated that $5 \mathrm{mmol} / \mathrm{L} \mathrm{Ca}$ could decrease the $\mathrm{Cd}$ levels significantly $(P<0.05)$ in roots, new stems, leave and old stems of $S$. matsudana exposed to all $\mathrm{Cd}$ concentrations used during the whole experiment. 
Table 3. Effect of exogenous Ca on Fe content in different organs of S. matsudana under different concentrations of Cd sress.

\begin{tabular}{|c|c|c|c|c|c|}
\hline \multirow{2}{*}{$\begin{array}{l}\text { Time } \\
\text { (d) }\end{array}$} & \multirow{2}{*}{$\begin{array}{c}\text { Treatment } \\
\mathrm{Cd}(\mu \mathrm{mol} / \mathrm{L}) \\
\mathrm{Ca}(\mathrm{mmol} / \mathrm{L})\end{array}$} & \multicolumn{4}{|c|}{$\mathrm{Fe}(\mu \mathrm{g} / \mathrm{g}, \mathrm{DW} \pm \mathrm{SE})$} \\
\hline & & Root & New stem & Leaf & Old stem \\
\hline \multirow{5}{*}{7} & 0 & $127.25 \pm 0.2 \mathrm{a}$ & $50.69 \pm 0.19 \mathrm{a}$ & $128.8 \pm 0.68 \mathrm{a}$ & $35.13 \pm 0.13 \mathrm{a}$ \\
\hline & $10 \mathrm{Cd}$ & $339.94 \pm 0.11 \mathrm{~b}$ & $37.22 \pm 0.04 b$ & $88.97 \pm 0.40 \mathrm{~b}$ & $23.02 \pm 0.34 \mathrm{~b}$ \\
\hline & $10 \mathrm{Cd}+5 \mathrm{Ca}$ & $279.13 \pm 0.23 \mathrm{c}$ & $45.79 \pm 0.18 \mathrm{c}$ & $68.30 \pm 0.40 \mathrm{c}$ & $28.73 \pm 0.07 \mathrm{c}$ \\
\hline & $50 \mathrm{Cd}$ & $307.09 \pm 0.12 \mathrm{~d}$ & $43.94 \pm 0.50 \mathrm{~d}$ & $72.36 \pm 0.11 \mathrm{~d}$ & $48.00 \pm 0.19 \mathrm{~d}$ \\
\hline & $50 \mathrm{Cd}+5 \mathrm{Ca}$ & $370.95 \pm 0.14 \mathrm{e}$ & $50.43 \pm 0.13 \mathrm{a}$ & $98.95 \pm 0.5 \mathrm{e}$ & $55.73 \pm 0.29 \mathrm{e}$ \\
\hline \multirow{5}{*}{14} & 0 & $254.31 \pm 0.14 \mathrm{a}$ & $49.1 \pm 0.01 \mathrm{a}$ & $120.55 \pm 0.56 \mathrm{a}$ & $19.68 \pm 0.11 \mathrm{a}$ \\
\hline & $10 \mathrm{Cd}$ & $487.21 \pm 0.21 \mathrm{~b}$ & $29.87 \pm 0.17 b$ & $77.06 \pm 0.16 \mathrm{~b}$ & $17.76 \pm 0.13 b$ \\
\hline & $10 \mathrm{Cd}+5 \mathrm{Ca}$ & $374.03 \pm 0.20 \mathrm{c}$ & $33.59 \pm 0.56 \mathrm{c}$ & $62.60 \pm 0.24 c$ & $24.58 \pm 0.04 \mathrm{c}$ \\
\hline & $50 \mathrm{Cd}$ & $498.78 \pm 0.23 \mathrm{~d}$ & $32.79 \pm 0.13 \mathrm{~d}$ & $69.85 \pm 0.17 \mathrm{~d}$ & $33.99 \pm 0.20 \mathrm{~d}$ \\
\hline & $50 \mathrm{Cd}+5 \mathrm{Ca}$ & $512.98 \pm 0.22 \mathrm{e}$ & $46.66 \pm 0.64 \mathrm{e}$ & $86.47 \pm 0.02 \mathrm{e}$ & $40.71 \pm 0.04 \mathrm{e}$ \\
\hline \multirow{5}{*}{21} & 0 & $267.93 \pm 0.45 \mathrm{a}$ & $44.5 \pm 0.14 \mathrm{a}$ & $112.24 \pm 0.46 \mathrm{a}$ & $17.53 \pm 0.04 \mathrm{a}$ \\
\hline & $10 \mathrm{Cd}$ & $570.17 \pm 0.56 b$ & $24.68 \pm 0.07 \mathrm{~b}$ & $63.13 \pm 0.31 \mathrm{~b}$ & $15.58 \pm 0.13 b$ \\
\hline & $10 \mathrm{Cd}+5 \mathrm{Ca}$ & $455.58 \pm 0.11 \mathrm{c}$ & $30.74 \pm 0.21 \mathrm{c}$ & $51.48 \pm 0.13 \mathrm{c}$ & $20.90 \pm 0.27 \mathrm{c}$ \\
\hline & $50 \mathrm{Cd}$ & $580.53 \pm 0.52 \mathrm{~d}$ & $25.16 \pm 0.25 \mathrm{~d}$ & $65.27 \pm 0.19 \mathrm{~d}$ & $25.13 \pm 0.13 \mathrm{~d}$ \\
\hline & $50 \mathrm{Cd}+5 \mathrm{Ca}$ & $613.97 \pm 0.54 \mathrm{e}$ & $32.78 \pm 0.21 \mathrm{e}$ & $83.68 \pm 0.45 \mathrm{e}$ & $34.68 \pm 0.28 \mathrm{e}$ \\
\hline \multirow{5}{*}{28} & 0 & $270.68 \pm 0.39 a$ & $38.26 \pm 0.11 \mathrm{a}$ & $102.68 \pm 0.43 \mathrm{a}$ & $15.58 \pm 0.29 \mathrm{a}$ \\
\hline & $10 \mathrm{Cd}$ & $628.1 \pm 0.61 \mathrm{~b}$ & $13.01 \pm 0.25 b$ & $53.63 \pm 0.08 b$ & $3.20 \pm 0.03 b$ \\
\hline & $10 \mathrm{Cd}+5 \mathrm{Ca}$ & $546.49 \pm 0.06 \mathrm{c}$ & $22.99 \pm 0.08 \mathrm{c}$ & $40.98 \pm 0.24 c$ & $6.89 \pm 0.22 \mathrm{c}$ \\
\hline & $50 \mathrm{Cd}$ & $765.49 \pm 0.64 d$ & $17.84 \pm 0.32 \mathrm{~d}$ & $63.47 \pm 0.46 \mathrm{~d}$ & $10.79 \pm 0.28 \mathrm{~d}$ \\
\hline & $50 \mathrm{Cd}+5 \mathrm{Ca}$ & $827.31 \pm 0.15 \mathrm{e}$ & $24.13 \pm 0.12 \mathrm{e}$ & $74.64 \pm 0.15 \mathrm{e}$ & $17.67 \pm 0.01 \mathrm{e}$ \\
\hline
\end{tabular}

Values followed by different letters differ significantly from each other $(P<0.05, t$-test $)$. Means $\pm \mathrm{SE}, \mathrm{n}=3$.

\section{Mn Content}

Statistical analysis showed the presence of significant correlations among the concentrations of $\mathrm{Cd}$ and microelements ( $\mathrm{Ca}$ and $\mathrm{Mn}$ ). The accumulation of $\mathrm{Mn}$ in S. matsudana roots, new stems, leaves and old stems varied with $\mathrm{Cd}$ concentration and treatment time. As shown in Table 2, in the presence of $\mathrm{Cd}$, the contents of $\mathrm{Mn}$ in roots, new stems, leaves and old stems of $S$. matsudana decreased significantly $(P<0.05)$ when compared to control. $5 \mathrm{mmol} / \mathrm{L} \mathrm{Ca}$ was found to increase Mn accumulation significantly $(P<0.05)$ in the different of $S$. matsudana stressed by $\mathrm{Cd}$ during the whole experiment in comparison with the Cd-treated groups (without $\mathrm{Ca}$ ) except for the root groups exposed to $10 \mu \mathrm{mol} / \mathrm{L} \mathrm{Cd}+5 \mathrm{mmol} / \mathrm{L} \mathrm{Ca}$ for $7,14,21$ and $28 \mathrm{~d}$. Data also showed that $5 \mathrm{mmol} / \mathrm{L}$ Ca could not promote the absorption of $\mathrm{Mn}$ in the roots treated with $10 \mu \mathrm{mol} / \mathrm{L}$ $\mathrm{Cd}$ during the duration of the experiment.

\section{Fe Content}

The contents of $\mathrm{Fe}$ in roots exposed to 10 and $50 \mu \mathrm{mol} / \mathrm{L} \mathrm{Cd}$ during the whole experiment were high significantly $(P<0.05)$ when compared to control (Table 3). However, the contents of Fe in new stems, leave and old stems of $S$. matsudana exposed to all $\mathrm{Cd}$ concentrations used during the whole experiment were observed to be low significantly $(P<0.05)$ in comparison with control. Effects of exogenous $\mathrm{Ca}(5 \mathrm{mmol} / \mathrm{L})$ on Fe accumulation of $S$. matsudana varied with the $\mathrm{Cd}$ concentration and the organs of $S$. matsudana. Data from Table 3 revealed that $5 \mathrm{mmol} / \mathrm{L} \mathrm{Ca}$ promoted the Fe uptake significantly $(P<0.05)$ in the roots exposed $50 \mu \mathrm{mol} / \mathrm{L} \mathrm{Cd}$ during the whole experiment. In the other organs (new stems, leaves and old stems), the exogenous $\mathrm{Ca}$ increased $\mathrm{Fe}$ accumulation in comparison with the groups treated with all $\mathrm{Cd}$ concentrations used except for the leaf groups exposed to $10 \mu \mathrm{mol} / \mathrm{L} \mathrm{Cd}$ for 7,14 , 21 and $28 \mathrm{~d}$. 
Table 4. Effect of exogenous Ca on Zn content in different organs of S. matsudana under different concentrations of Cd sress.

\begin{tabular}{|c|c|c|c|c|c|}
\hline \multirow{2}{*}{$\begin{array}{l}\text { Time } \\
\text { (d) }\end{array}$} & \multirow{2}{*}{$\begin{array}{c}\text { Treatment } \\
\mathrm{Cd}(\mu \mathrm{mol} / \mathrm{L}) \\
\mathrm{Ca}(\mathrm{mmol} / \mathrm{L})\end{array}$} & \multicolumn{4}{|c|}{$\mathrm{Zn}(\mu \mathrm{g} / \mathrm{g}, \mathrm{DW} \pm \mathrm{SE})$} \\
\hline & & Root & New stem & Leaf & Old stem \\
\hline \multirow{5}{*}{7} & 0 & $152.26 \pm 0.88 \mathrm{a}$ & $181.31 \pm 0.17 \mathrm{a}$ & $146.79 \pm 0.22 \mathrm{a}$ & $28.75 \pm 0.04 \mathrm{a}$ \\
\hline & $10 \mathrm{Cd}$ & $237.26 \pm 0.07 b$ & $131.92 \pm 0.14 b$ & $109.76 \pm 0.10 \mathrm{~b}$ & $29.93 \pm 0.14 b$ \\
\hline & $10 \mathrm{Cd}+5 \mathrm{Ca}$ & $304.28 \pm 0.23 \mathrm{c}$ & $161.23 \pm 0.23 \mathrm{c}$ & $117.47 \pm 0.30 \mathrm{c}$ & $30.35 \pm 0.05 \mathrm{c}$ \\
\hline & $50 \mathrm{Cd}$ & $196.09 \pm 0.28 \mathrm{~d}$ & $103.10 \pm 0.67 \mathrm{~d}$ & $100.61 \pm 0.09 \mathrm{~d}$ & $27.77 \pm 0.05 \mathrm{~d}$ \\
\hline & $50 \mathrm{Cd}+5 \mathrm{Ca}$ & $255.07 \pm 1.02 \mathrm{e}$ & $154.85 \pm 0.15 \mathrm{e}$ & $127.00 \pm 0.29 \mathrm{e}$ & $29.07 \pm 0.09 \mathrm{e}$ \\
\hline \multirow{5}{*}{14} & 0 & $140.74 \pm 0.63 \mathrm{a}$ & $147.73 \pm 0.26 \mathrm{a}$ & $156.65 \pm 0.23 \mathrm{a}$ & $26.12 \pm 0.26 \mathrm{a}$ \\
\hline & $10 \mathrm{Cd}$ & $224.94 \pm 0.28 b$ & $126.72 \pm 0.40 \mathrm{~b}$ & $126.92 \pm 0.18 b$ & $27.05 \pm 0.01 \mathrm{~b}$ \\
\hline & $10 \mathrm{Cd}+5 \mathrm{Ca}$ & $273.41 \pm 0.61 \mathrm{c}$ & $134.48 \pm 0.22 \mathrm{c}$ & $146.42 \pm 0.31 \mathrm{c}$ & $29.95 \pm 0.16 \mathrm{c}$ \\
\hline & $50 \mathrm{Cd}$ & $173.87 \pm 0.37 \mathrm{~d}$ & $98.52 \pm 0.22 \mathrm{~d}$ & $116.17 \pm 0.17 \mathrm{~d}$ & $25.44 \pm 0.12 \mathrm{~d}$ \\
\hline & $50 \mathrm{Cd}+5 \mathrm{Ca}$ & $238.25 \pm 0.48 \mathrm{e}$ & $120.06 \pm 0.06 \mathrm{e}$ & $149.44 \pm 0.14 \mathrm{e}$ & $27.68 \pm 0.01 \mathrm{e}$ \\
\hline \multirow{5}{*}{21} & 0 & $131.85 \pm 0.19 \mathrm{a}$ & $129.57 \pm 0.17 \mathrm{a}$ & $171.67 \pm 0.27 \mathrm{a}$ & $25.14 \pm 0.10 \mathrm{a}$ \\
\hline & $10 \mathrm{Cd}$ & $212.96 \pm 0.17 b$ & $97.65 \pm 0.12 b$ & $143.56 \pm 0.15 b$ & $26.23 \pm 0.10 \mathrm{~b}$ \\
\hline & $10 \mathrm{Cd}+5 \mathrm{Ca}$ & $242.64 \pm 0.15 \mathrm{c}$ & $112.15 \pm 0.17 \mathrm{c}$ & $163.62 \pm 0.19 \mathrm{c}$ & $28.09 \pm 0.23 \mathrm{c}$ \\
\hline & $50 \mathrm{Cd}$ & $164.84 \pm 0.18 \mathrm{~d}$ & $84.97 \pm 0.35 \mathrm{~d}$ & $121.39 \pm 0.22 \mathrm{~d}$ & $18.73 \pm 0.13 \mathrm{~d}$ \\
\hline & $50 \mathrm{Cd}+5 \mathrm{Ca}$ & $201.94 \pm 0.64 \mathrm{e}$ & $97.05 \pm 0.47 \mathrm{e}$ & $156.60 \pm 0.64 \mathrm{e}$ & $22.28 \pm 0.23 \mathrm{e}$ \\
\hline \multirow{5}{*}{28} & 0 & $87.50 \pm 0.11 \mathrm{a}$ & $109.86 \pm 0.23 \mathrm{a}$ & $180.91 \pm 0.44 \mathrm{a}$ & $24.00 \pm 0.09 \mathrm{a}$ \\
\hline & $10 \mathrm{Cd}$ & $201.58 \pm 0.24 b$ & $87.39 \pm 0.18 b$ & $168.07 \pm 0.35 b$ & $24.76 \pm 0.04 \mathrm{~b}$ \\
\hline & $10 \mathrm{Cd}+5 \mathrm{Ca}$ & $230.96 \pm 0.24 \mathrm{c}$ & $91.87 \pm 0.25 b$ & $175.95 \pm 0.24 \mathrm{c}$ & $25.66 \pm 0.19 \mathrm{c}$ \\
\hline & $50 \mathrm{Cd}$ & $141.89 \pm 0.20 \mathrm{~d}$ & $80.68 \pm 0.34 \mathrm{c}$ & $141.18 \pm 0.46 \mathrm{~d}$ & $16.84 \pm 0.10 \mathrm{~d}$ \\
\hline & $50 \mathrm{Cd}+5 \mathrm{Ca}$ & $196.53 \pm 0.29 \mathrm{e}$ & $84.39 \pm 0.01 b$ & $171.30 \pm 0.32 \mathrm{e}$ & $20.40 \pm 0.28 \mathrm{e}$ \\
\hline
\end{tabular}

Values followed by different letters differ significantly from each other $(P<0.05, t$-test $)$. Means $\pm \mathrm{SE}, \mathrm{n}=3$.

\section{Zn Content}

The $\mathrm{Zn}$ contents in different organs of S. matsudana were examined. The effects of $\mathrm{Cd}$ on $\mathrm{Zn}$ uptake and accumulation are shown in Table 4 . The results indicated that $\mathrm{Zn}$ contents increased significantly $(P<0.05)$ in the roots exposed to 10 and $50 \mu \mathrm{mol} / \mathrm{L} \mathrm{Cd}$ and the old stems treated with $10 \mu \mathrm{mol} / \mathrm{L} \mathrm{Cd}$ during the whole experiment when compared with control. But $\mathrm{Zn}$ levels in new stems and leaves stressed by 10 and $50 \mu \mathrm{mol} / \mathrm{L} \mathrm{Cd}$ and the old stems exposed to $50 \mu \mathrm{mol} / \mathrm{L} \mathrm{Cd}$ decreased significantly $(P<0.05)$. Table 4 showed that the exogenous $\mathrm{Ca}$ $(5 \mathrm{mmol} / \mathrm{L})$ could promote the $\mathrm{Zn}$ contents significantly $(P<0.05)$ in all organs of $S$. matsudana exposed to $\mathrm{Cd}$ during the whole experiment time versus controls (the organs treated with $\mathrm{Cd}$ but not adding exogenous $\mathrm{Ca})$.

\section{$\mathrm{Cu}$ Content}

Effects of $\mathrm{Cd}$ on $\mathrm{Cu}$ levels in roots, new stems, leaves and old stems of $S$. matsudana varied with the different concentration of $\mathrm{Cd}$ and duration of treatment
(Table 5). The $\mathrm{Cu}$ levels in roots exposed to $50 \mu \mathrm{mol} / \mathrm{L}$ $\mathrm{Cd}$ during the whole experiment time were observed to be high significantly $(P<0.05)$ in comparison with control, but the $\mathrm{Cu}$ levels in roots treated with $10 \mu \mathrm{mol} / \mathrm{L}$ Cd decreased significantly (Table 5). As compared with control, the contents of $\mathrm{Cu}$ in new stem, leaf and old stem exposed to $10 \mu \mathrm{mol} / \mathrm{L} \mathrm{Cd}$ increased significantly $(P<0.05)$ during the whole treatment time. But, at high $\mathrm{Cd}$ concentration $(50 \mu \mathrm{mol} / \mathrm{L})$, the $\mathrm{Cu}$ contents in new stem and old stem were noted to be low significantly $(P<0.05)$, except for the new stem treated with $\mathrm{Cd}$ for $7 \mathrm{~d}$. Data from Table 5 also revealed that the level of $\mathrm{Cu}$ in the leaf groups exposed to $50 \mu \mathrm{mol} / \mathrm{L} \mathrm{Cd}$ was noted to be high significantly when compared with control during whole experimental cycle, except for the $28^{\text {th }} \mathrm{d}$. The effects of $\mathrm{Ca}$ on $\mathrm{Cu}$ concentration in the organs of $S$. matsudana under $\mathrm{Cd}$ stress are presented in Table 5. The $\mathrm{Cu}$ contents in roots exposed to $10 \mu \mathrm{mol} / \mathrm{L}$ $\mathrm{Cd}$ were noted to be high significantly $(P<0.05)$ during the duration of the experiment, but the contents in roots treated with $50 \mu \mathrm{mol} / \mathrm{L} \mathrm{Cd}$ decreased significantly. The exogenous $\mathrm{Ca}(5 \mathrm{mmol} / \mathrm{L})$ showed the decreasing trend in the contents of new stems exposed to 
Table 5. Effect of exogenous $\mathrm{Ca}$ on $\mathrm{Cu}$ content in different organs of S. matsudana under different concentrations of Cd sress.

\begin{tabular}{|c|c|c|c|c|c|}
\hline \multirow{2}{*}{$\begin{array}{l}\text { Time } \\
\text { (d) }\end{array}$} & \multirow{2}{*}{$\begin{array}{c}\text { Treatment } \\
\mathrm{Cd}(\mu \mathrm{mol} / \mathrm{L}) \\
\mathrm{Ca}(\mathrm{mmol} / \mathrm{L})\end{array}$} & \multicolumn{4}{|c|}{$\mathrm{Cu}(\mu \mathrm{g} / \mathrm{g}, \mathrm{DW} \pm \mathrm{SE})$} \\
\hline & & Root & New stem & Leaf & Old stem \\
\hline \multirow{5}{*}{7} & 0 & $28.52 \pm 0.08 \mathrm{a}$ & $26.02 \pm 0.11 \mathrm{a}$ & $13.64 \pm 0.10 \mathrm{a}$ & $18.78 \pm 0.10 \mathrm{a}$ \\
\hline & $10 \mathrm{Cd}$ & $13.05 \pm 0.16 \mathrm{~b}$ & $35.39 \pm 0.19 b$ & $39.33 \pm 0.13 b$ & $25.91 \pm 0.32 b$ \\
\hline & $10 \mathrm{Cd}+5 \mathrm{Ca}$ & $41.51 \pm 0.08 \mathrm{c}$ & $35.35 \pm 0.23 b$ & $36.18 \pm 0.28 \mathrm{c}$ & $25.56 \pm 0.17 b$ \\
\hline & $50 \mathrm{Cd}$ & $36.01 \pm 0.19 \mathrm{~d}$ & $25.73 \pm 0.12 \mathrm{a}$ & $22.43 \pm 0.10 \mathrm{~d}$ & $16.80 \pm 0.26 \mathrm{c}$ \\
\hline & $50 \mathrm{Cd}+5 \mathrm{Ca}$ & $27.08 \pm 0.13 \mathrm{e}$ & $18.16 \pm 0.24 \mathrm{c}$ & $11.5 \pm 0.09 \mathrm{e}$ & $9.35 \pm 0.04 d$ \\
\hline \multirow{5}{*}{14} & 0 & $30.95 \pm 0.14 \mathrm{a}$ & $27.44 \pm 0.12 \mathrm{a}$ & $16.15 \pm 0.12 \mathrm{a}$ & $19.51 \pm 0.18 \mathrm{a}$ \\
\hline & $10 \mathrm{Cd}$ & $17.86 \pm 0.09 \mathrm{~b}$ & $36.15 \pm 0.19 b$ & $38.54 \pm 0.25 b$ & $23.99 \pm 0.12 b$ \\
\hline & $10 \mathrm{Cd}+5 \mathrm{Ca}$ & $48.40 \pm 0.09 \mathrm{c}$ & $36.36 \pm 0.07 \mathrm{~b}$ & $33.59 \pm 0.02 \mathrm{c}$ & $24.70 \pm 0.14 \mathrm{c}$ \\
\hline & $50 \mathrm{Cd}$ & $51.04 \pm 0.13 \mathrm{~d}$ & $24.41 \pm 0.28 \mathrm{c}$ & $22.6 \pm 0.04 d$ & $15.74 \pm 0.03 \mathrm{~d}$ \\
\hline & $50 \mathrm{Cd}+5 \mathrm{Ca}$ & $39.8 \pm 0.03 \mathrm{e}$ & $13.65 \pm 0.04 \mathrm{~d}$ & $10.52 \pm 0.09 \mathrm{e}$ & $8.94 \pm 0.21 \mathrm{e}$ \\
\hline \multirow{5}{*}{21} & 0 & $31.28 \pm 0.15 \mathrm{a}$ & $28.42 \pm 0.12 \mathrm{a}$ & $21.23 \pm 0.24 \mathrm{a}$ & $20.13 \pm 0.08 \mathrm{a}$ \\
\hline & $10 \mathrm{Cd}$ & $21.45 \pm 0.04 \mathrm{~b}$ & $30.78 \pm 0.25 b$ & $36.80 \pm 0.08 b$ & $23.49 \pm 0.14 \mathrm{~b}$ \\
\hline & $10 \mathrm{Cd}+5 \mathrm{Ca}$ & $51.89 \pm 0.09 \mathrm{c}$ & $30.65 \pm 0.08 b$ & $32.91 \pm 0.07 \mathrm{c}$ & $24.28 \pm 0.13 \mathrm{c}$ \\
\hline & $50 \mathrm{Cd}$ & $61.11 \pm 0.14 \mathrm{~d}$ & $23.8 \pm 0.13 \mathrm{c}$ & $21.91 \pm 0.16 \mathrm{~d}$ & $16.70 \pm 0.12 \mathrm{~d}$ \\
\hline & $50 \mathrm{Cd}+5 \mathrm{Ca}$ & $49.92 \pm 0.15 \mathrm{e}$ & $11.71 \pm 0.01 \mathrm{~d}$ & $9.95 \pm 0.23 \mathrm{e}$ & $8.20 \pm 0.22 \mathrm{e}$ \\
\hline \multirow{5}{*}{28} & 0 & $32.46 \pm 0.03 \mathrm{a}$ & $28.86 \pm 0.27 \mathrm{a}$ & $22.15 \pm 0.19 \mathrm{a}$ & $23.81 \pm 0.12 \mathrm{a}$ \\
\hline & $10 \mathrm{Cd}$ & $32.09 \pm 0.15 b$ & $33.24 \pm 0.15 b$ & $35.70 \pm 0.30 \mathrm{~b}$ & $23.51 \pm 0.10 b$ \\
\hline & $10 \mathrm{Cd}+5 \mathrm{Ca}$ & $55.74 \pm 0.01 \mathrm{c}$ & $33.63 \pm 0.18 b$ & $32.33 \pm 0.04 \mathrm{c}$ & $24.68 \pm 0.02 \mathrm{c}$ \\
\hline & $50 \mathrm{Cd}$ & $81.78 \pm 0.16 \mathrm{~d}$ & $22.34 \pm 0.12 \mathrm{c}$ & $20.13 \pm 0.14 d$ & $16.15 \pm 0.17 \mathrm{~d}$ \\
\hline & $50 \mathrm{Cd}+5 \mathrm{Ca}$ & $61.61 \pm 0.10 \mathrm{e}$ & $9.56 \pm 0.21 \mathrm{~d}$ & $9.32 \pm 0.12 \mathrm{e}$ & $8.82 \pm 0.22 \mathrm{e}$ \\
\hline
\end{tabular}

Values followed by different letters differ significantly from each other $(P<0.05, t$-test $)$. Means $\pm \mathrm{SE}, \mathrm{n}=3$.

$50 \mu \mathrm{mol} / \mathrm{LCd}$, while there was no significant difference at $10 \mu \mathrm{mol} / \mathrm{L} \mathrm{Cd}$. The levels of $\mathrm{Cu}$ in leaves of $S$. matsudana stressed by $\mathrm{Cd}$ had a decreasing trend with increasing $\mathrm{Cd}$ concentration and duration of treatment. Data from Table 5 also showed that the exogenous $\mathrm{Ca}$ could induce the significantly low contents of old stems stressed with $50 \mu \mathrm{mol} / \mathrm{L} \mathrm{Cd}$.

\section{Discussion}

Accumulation of $\mathrm{Cd}$ often results in visible plant symptoms, such as stunted growth, leaf chlorosis, browning of roots and alteration in the activities of many key enzymes in various metabolic pathways [19, 22,23$]$. In the present investigation, reductions in root and shoot length of $S$. matsudana were observed with increasing $\mathrm{Cd}$ concentrations. The effect of $\mathrm{Cd}$ on root lengths reduction of $S$. matsudana was more remarkable than that of shoots, because the root was the organ directly exposed to $\mathrm{Cd}$, which were consistent with earlier findings by Stravin-skienè and Račaite [24] in Trifolium repens L. S. matsudana has the ability to accumulate
Cd primarily in its roots, and transport and concentrate it in its stems and levels in much lesser concentrations. The distribution may be due to the mobilization of the protective mechanisms of plants, which inhibits the transport to further tissues and organs [22]. The results obtained here are consistent with earlier findings [20-22, $25,26]$.

$\mathrm{Ca}$ is an essential plant macronutrient that involved in various plant physiological processes, such as plant growth and development, cell division, cytoplasmic streaming, photosynthesis and intracellular signaling transduction [23, 27, 28]. Some research works demonstrated that $\mathrm{Ca}$ could regulate a range of activities within the cell, such as cell division and elongation, cytoplasmic streaming, photomorphogenesis and plant defense against environmental stresses [29-33]. Several reports indicated that $\mathrm{Ca}$ could compete with $\mathrm{Cd}$ in plants to increase the tolerance of plants to heavy metals and reduce the damage caused by heavy metals to plants $[34,35]$. Ca alleviates Cd-induced oxidative stress in plants by scavenging reactive oxygen species (ROS), increasing antioxidant levels and enhancing antioxidant enzymes activities [28]. $\mathrm{Cd}$ and $\mathrm{Ca}$ have similar ionic 
radii (0.099 $\mathrm{nm}$ and $0.097 \mathrm{~nm}$, respectively) and compete for the same Ca channels in plants [36]. Shortly after $\mathrm{Cd}$ enters the cytoplasm, it binds to certain sites in the root tip apoplast, affecting the function of the plasma lemma pumps transporting $\mathrm{Ca}$ ions and resulting in the interference of $\mathrm{Ca}$ uptake [7]. The results here showed that the exogenous $5 \mathrm{mmol} / \mathrm{L} \mathrm{Ca}$ could decrease the $\mathrm{Cd}$ levels significantly $(P<0.05)$ in the organs of $S$. matsudana exposed to all $\mathrm{Cd}$ concentrations used during the whole experiment, revealing that $\mathrm{Ca}$ had the alleviating toxic effects on the seedling growth stressed by $\mathrm{Cd}$. Previous studies indicated that the increase of Ca concentration in roots of Brassica juncea [37] and Hordeum vulgare [38] under Cd stress was a potential mechanism for reducing the toxic effects of $\mathrm{Cd}$. The phenomenon may possibly be explained by the fact that when $\mathrm{Ca}$ and $\mathrm{Cd}$ coexist in the adsorption system, $\mathrm{Ca}$ can reduce the adsorption of $\mathrm{Cd}$, thereby reduce the toxic effect of $\mathrm{Cd}$ on plants [39]. $\mathrm{Xu}$ et al. [27] also showed that as with the essential micronutrients, Cd was taken up by plants due its physicochemical similarity to other cations (such as $\mathrm{Ca}$ ); consequently, $\mathrm{Cd}$ could compete with $\mathrm{Ca}$ and enter the plant through transport systems meant for $\mathrm{Ca}$. The results demonstrated that low concentration of $\mathrm{Ca}$ treatment also enhanced the uptake of Cd in the roots of Brassica juncea, Sesbania sesban and Boehmeria nivea [40, 41], suggesting increased the phytotoxicity of Cd. Other studies pointed out that plant treated with heavy metals often increases suberin and lignin contents [42]. Studies conducted by Baxter et al., [43] and Zeng et al. [23] indicated that lignin was mainly found in the cell wall of the inner and outer cortex of the roots, and also played an important role to regulate the absorption of water and mineral elements. Under Cd stress, the expression of genes was involved in lignin synthesis. As lignin accumulates, root cell membrane integrity is lost in Cd-treated plants, resulting in the adherence of $\mathrm{Cd}$ to its root surface stronger when compared with $\mathrm{Cd}+\mathrm{Ca}$-treated plants. In this way the growth of primary root in Cd-treated plants is inhibited more severely [23].

$\mathrm{Cu}, \mathrm{Fe}, \mathrm{Mn}$ and $\mathrm{Zn}$ are metal micronutrients that play an essential role in plant cell growth and development [44]. Dynamic equilibrium of these heavy metals in plant cells is necessary to avoid deficiency and toxicity [13]. As indicated by Liu et al. [45], the interactions of $\mathrm{Cd}$ and $\mathrm{Fe}, \mathrm{Cu}$ and $\mathrm{Zn}$ were synergetic in uptake and translocation from root to shoot by rice plants. It well demonstrated that $\mathrm{Cd}$ could alter the uptake of minerals by plants through its effects on the availability of minerals from the soil. Cd toxicity may affect plant metabolism, disturbing the accumulation and translocation of mineral nutrient. Plants have a complex metal homeostasis network system that regulates the uptake and distribution of some basic elements in order to ensure the normal metabolic processes [21]. $\mathrm{Cd}$ is transported via cation channels or by other elemental transporters, an increase in the $\mathrm{Cd}$ concentration in the soil will lead to ion competition and result in an antagonistic interaction between $\mathrm{Cd}$ and other elements in the plant $[5,46]$. In the present study, we detected the $\mathrm{Zn}, \mathrm{Fe}, \mathrm{Mn}$ and $\mathrm{Cu}$ contents of root and shoot exposed to 10 to $50 \mu \mathrm{mol} / \mathrm{L} \mathrm{Cd}$. Accumulating $\mathrm{Cd}$ to different organs of $S$. matsudana had an obvious impact on the uptake of $\mathrm{Cu}, \mathrm{Fe}, \mathrm{Mn}$, and $\mathrm{Zn}$ in the present investigation. The concentration of $\mathrm{Mn}$ in roots and shoots was significantly decreased, which agreed with previous studies $[20,21,22,26]$. In contrast with $\mathrm{Mn}$, the concentrations of $\mathrm{Cu}, \mathrm{Zn}$, and $\mathrm{Fe}$ in roots $S$. matsudana were significantly increased under $\mathrm{Cd}$ stress in this study. D'Alessandro et al. [47] demonstrated that $\mathrm{Cd}$ shares chemical similarity to $\mathrm{Zn}, \mathrm{Fe}$, and Mn and may compete with them for translocation in plants. Therefore, $\mathrm{Cd}$ can selectively share different micronutrient uptake and translocation pathway in plants, and further affect the plant growth [26]. Data from the present investigation also revealed that the concentrations of $\mathrm{Zn}$ and $\mathrm{Fe}$ in shoots of $S$. matsudana treated with all the $\mathrm{Cd}$ concentrations, and the shoots of $\mathrm{Cu}$ at $50 \mu \mathrm{mol} / \mathrm{L}$ $\mathrm{Cd}$ decreased significantly. The trend may be explained by the fact that $\mathrm{Cd}$ accumulates mainly in roots, only small amounts translocate to shoots. Therefore, the low $\mathrm{Cd}$ level in shoot may not cause significant affection to $\mathrm{Zn}, \mathrm{Fe}$ and $\mathrm{Cu}$ [26]. As indicated by Stravin-skiene and Račaite [24], the addition of exogenous $\mathrm{Ca}$ contributes to an enhancement of the essential mineral elements uptake and these elements are beneficial to plant growth and development. Data from the present investigation also indicated that exogenous $\mathrm{Ca}$ could promote the absorption of $\mathrm{Cu}, \mathrm{Fe}, \mathrm{Zn}$ and $\mathrm{Mn}$ in roots and shoots of S. matsudana to different extent, suggesting that $\mathrm{Ca}$ has alleviating effects on the toxicity of $\mathrm{Cd}$. The information available in the present investigation is an important step towards obtaining a better understanding of $\mathrm{Ca}$ on the alleviation of $\mathrm{Cd}$ toxicity in plants and its effects on other minerals.

Exogenous $\mathrm{Ca}$ reduced $\mathrm{Cd}$ uptake mainly by reducing its root adsorption and changing its transport mode. In soil, $\mathrm{Ca}$ can reduce the $\mathrm{Cd}$ absorption of plants. On the one hand, because $\mathrm{Ca}$ and $\mathrm{Cd}$ have similar chemical properties, $\mathrm{Ca}$ is the main competitor of $\mathrm{Cd}$ adsorption sites in soil. When $\mathrm{Ca}$ and $\mathrm{Cd}$ coexist in the adsorption system, $\mathrm{Ca}$ can reduce soil to $\mathrm{Cd}$ adsorption, thereby reducing the toxic effects of $\mathrm{Cd}$ on plants. On the other hand, glutamate is a wound signal in plants, ion channels of the Glutamate receptorlike family act as sensors that convert this signal into an increase in intracellular $\mathrm{Ca}$ ion concentration that propagates to distant organs, where defense responses are then induced [48]. Ca ion plays an important role as the second messenger, which can couple extracellular signals with intracellular physiological and biochemical reactions, enhancing plant resistance to environmental stress by stabilizing cell wall, cell membrane structure and inducing the expression of a series of specific genes. Plants sense local signals, and transmit this information throughout the plant body to rapidly activate defense responses in undamaged parts. Therefore, exogenous 
$\mathrm{Ca}$ increased the intracellular $\mathrm{Ca}$ ion concentration of S. matsudana, thereby reducing the toxic effects of $\mathrm{Cd}$ on $S$. matsudana.

\section{Conclusions}

Based on the information provided in this article, it is concluded that:

1. Cd could inhibit the growth of $S$. matsudana seedling, and $5 \mathrm{mmol} / \mathrm{L} \mathrm{Ca}$ had an alleviating toxic effects on seedlings' growth.

2. Exogenous $\mathrm{Ca}(5 \mathrm{mmol} / \mathrm{L})$ could decrease the $\mathrm{Cd}$ levels significantly $(P<0.05)$ in different organs of $S$. matsudana exposed to all Cd concentrations used during the whole experiment, revealing that $\mathrm{Ca}$ can be used to alleviate the harmful effect of $\mathrm{Cd}$.

3. The concentrations of $\mathrm{Cu}, \mathrm{Zn}$, and $\mathrm{Fe}$ in roots $S$. matsudana were significantly increased under $\mathrm{Cd}$ stress, and the concentration of $\mathrm{Mn}$ in roots and shoots was significantly decreased by $\mathrm{Cd}$ stress.

4. Exogenous $\mathrm{Ca}$ could promote the absorption of $\mathrm{Cu}$, $\mathrm{Fe}, \mathrm{Zn}$ and $\mathrm{Mn}$ in roots and shoots of $S$. matsudana to different extent, suggesting that $\mathrm{Ca}$ has alleviating effects on the toxicity of $\mathrm{Cd}$.

\section{Acknowledgements}

This project was supported by the Natural Science Foundation of China (grant No. 31901184) and the Natural Science Foundation of Tianjin, China (grant No. 17JCYBJC22500) and Doctor Foundation of Tianjin Normal University (grant No. 52XB1914). The authors wish to express their appreciation to the reviewers for their comments and suggestions.

\section{Conflict of Interest}

The authors declare no conflict of interest.

\section{References}

1. EL-Beltagi H.S., MOHAMED H.I. Alleviation of Cadmium Toxicity in Pisum sativum L. Seedlings by Calcium Chloride. Not. Bot. Horti. Agrobo. 41, 157, 2013.

2. BI X.Y., FENG X.B., YANG Y.G., LI X.D., SHIN G.P.Y., LI F.L., QIU G.L., LI G.H., LIU T.Z., FU Z.Y. Allocation and Source Attribution of Lead and Cadmium in Maize (Zea Mays L.) Impacted by Smelting Emissions. Environ. Pollut. 157, 834, 2009.

3. RIZWAN M., MEUNIER J.D., DAVIDIAN J.C., POKROVSKY O.S., BOVET N., KELLER C. Silicon alleviates Cd stress of wheat seedlings (Triticum turgidum L. cv. Claudio) grown in hydroponics. Environ. Sci. Pollut. R. 23, 1414, 2016.
4. HÉDIJI H., DJEBALI W., BELKADHI A., CABASSON C., MOING A., ROLIN D., BROUQUISSE R., GALLUSCI P., CHAIBI W. Impact of long-term cadmium exposure on mineral content of Solanum lycopersicum plants: consequences on fruit production. S. Afr. J. Bot. 97, 176, 2015.

5. ZHANG X.F., ZHANG X.H., GAO B., LI Z.A., XIA H.P., LI H.F., LI J. Effect of cadmium on growth, photosynthesis, mineral nutrition and metal accumulation of an energy crop, king grass (Pennisetum americanum $\times$ P. purpureum). Biomass Bioenerg. 67, 179, 2014.

6. TOMAR P.C., LAKRA N., MISHRA S.N. Effect of cadaverine on Brassica juncea (L.) under multiple stress. Indian. J. Exp. Biol. 51, 758, 2013.

7. WU H.F., WANG J.Y., LI B.B., OU Y.J., JIANG W.S., LIU D.H., ZOU J.H. Uptake and Accumulation of Cadmium and Relative Gene Expression in Roots of Cd-resistant Salix matsudana Koidz. Pol. J. Environ. Stud. 25, 2717, 2016.

8. SHI Q.Y., WANG J.R., ZOU J.H., JIANG Z., WANG J.Y., WU H.F., JIANG W.S., LIU D.H. Cadmium uptake and accumulation and its toxic effects on leaves in Hordeum vulgare. Fresen. Environ. Bull.24, 4504, 2015.

9. SHI Q.Y., WANG J.R., ZOU J.H., JIANG Z., WANG J.Y., WU H.F., JIANG W.S., LIU D.H. Cd subcellular localization in root tips of Hordeum vulgare. Pol. J. Environ. Stud. 25, 903, 2016.

10. DENG G., LI M., LI H., YIN L.Y., LI W. Exposure to cadmium causes declines in growth and photosynthesis in the endangered aquatic fern (Ceratopteris pteridoides). Aquat. Bot. 112, 23, 2014.

11. OSMOLOVSKAYA N.G., DUNG V.V., KUDRYASHOVA Z.K., KUCHAEVA L.N., POPOVA N.F. Effect of Cadmium on Distribution of Potassium, Calcium, Magnesium, and Oxalate Accumulation in Amaranthus cruentus L. Plants. Russ. J. Plant Physl. 65, 553, 2018.

12. FERROL N., TAMAYO E., VARGAS P. The heavy metal paradox in arbuscular mycorrhizas: from mechanisms to biotechnological applications. J. Exp. Bot. 67, 6253, 2016.

13. CHOPPALA G., SAIFULLAH, BOLAN N., BIBI S., IQBAL M., RENGEL Z., KUNHIKRISHNAN A., ASHWATH N., OK Y.S. Cellular mechanisms in higher plants governing tolerance to cadmium toxicity. Crit. Rev. Plant Sci. 33, 374, 2014.

14. CHEVAL C., ALDON D., GALAUD J.P., RANTY B. Calcium/calmodulin-mediated regulation of plant immunity. BBA-Mol. Cell Res. 1833, 1766, 2013.

15. POOVAIAH B.W., DU L.Q., WANG H.Z., YANG T.B. Recent Advances in Calcium/Calmodulin-Mediated Signaling with an Emphasis on Plant-Microbe Interactions. Plant Physiol.163, 531, 2013.

16. CHEONG Y.H., SUNG S.J., KIM B.G., PANDEY G.K., CHO J.S.,.KIM K.N., LUAN S. Constitutive overexpression of the calcium sensor CBL5 confers osmotic or drought stress tolerance in Arabidopsis. Mol. Cells. 29, 159, 2010.

17. YANG J.L., CHEN Z., WU S.Q., CUI Y., ZHANG L., DONG H., YANG C.P., LI. C.H. Overexpression of the Tamarix Hispida ThMT3 Gene Increases Copper Tolerance and Adventitious Root Induction in $S$ alix Matsudana Koidz. Plant Cell Tiss. Org. 121, 469, 2015.

18. YANG J.X., LI X.L., HU Y.B., GAO L.M., YAO D.X. Enrichment Characteristics of heavy metal cadmium in woody plants system. Kem. Ind. 64, 283, 2015. 
19. ZOU J.H., WANG G., JI J., WANG J.Y., WU H.F., OU Y.J., LI B.B. Transcriptional, physiological and cytological analysis validated the roles of some key genes linked $\mathrm{Cd}$ stress in Salix matsudana Koidz. Environ. Exp. Bot. 134, 116, 2017.

20. WU H.F., WANG J.Y., LI B.B., OU Y.J., WANG J.R., SHI Q.Y., JIANG W.S., LIU D.H., ZOU J.H. Salix matsudana Koidz Tolerance Mechanisms to Cadmium: Uptake and Accumulation, Subcellular Distribution, and Chemical Forms. Pol. J. Environ. Stud. 25, 1739, 2016.

21. ZOU J.H., SHANG X.S. LI C.H., OU Y.J., LI B.B., Liu X.J. Effects of Cadmium on Mineral Metabolism and Antioxidant Enzyme Activities in Salix matsudana Koidz. Pol. J. Environ. Stud. 28, 989, 2019.

22. SUN S., LI M., ZOU J.H., JIANG W.S., LIU D.H. Cadmium effects on mineral accumulation, antioxidant defence system and gas exchange in cucumber. Zemdirbyste.102, 193, 2015.

23. ZENG L.H., ZHU T., GAO Y., WANG Y.T., NING C.J., BJÖRN L.O., CHEN D., LI S.H. Effects of Ca addition on the uptake, translocation, and distribution of $\mathrm{Cd}$ in Arabidopsis thaliana. Ecotox. Environ. Safe. 139, 228, 2017.

24. STRAVINSKIENĖ V., RAČAITĖ M. Impact of cadmium and zinc on the growth of white clover (Trifolium repens L.) shoots and roots. Pol. J. Environ. Stud.23, 1355, 2014.

25. OUYANG J., LI B.B., LI C.H., SHANG X.S., ZOU J.H. Cadmium Effects on Mineral Accumulation and Selected Physiological and Biochemical Characters of Salix babylonica L. Pol. J. Environ. Stud.26, 2667, 2017.

26. LI N.N., LI S.T., WANG S.F., XIE D.T., LUO F. How exogenous cadmium affects micronutrients accumulation and the related gene expression regulation in Brassica juncea. Int. J. Agric. Biol. 20, 2074, 2018.

27. XU Q.S., MIN H.L., CAI S.J., FU Y.Y., SHA S., XIE K.B., DU K.H. Subcellular distribution and toxicity of cadmium in Potamogeton crispus L. Chemosphere. 89, 114, 2012.

28. HUANG D.L., GONG X.M., LIU Y.G., ZENG G.M., LAI C., BASHIR H., ZHOU L., WANG D.F., XU P., CHENG M., WAN J. Effects of calcium at toxic concentrations of cadmium in plants. Planta. 245, 863, 2017.

29. AHMAD P., BHARDWAJ R., TUTEJA N. Plant signaling under abiotic stress environment. In: P. Ahmad and M.N.V. Prasad (eds.), Adaptations and Stress Tolerance of Plants in the Era of Climate Change. Springer Science+Business Media, LLC, 297, 2012

30. SARWAT M., AHMAD P., NABI G., HU X.Y. $\mathrm{Ca}^{2+}$ signals: The versatile decoders of environmental cues. Crit. Rev. Biotechnol. 33, 97, 2013.

31. ANDOSCH A., AFFENZELLER M.J., LÜTZ, C., LÜTZMEINDL U. A freshwater green alga under cadmium stress: ameliorating calcium effects on ultrastructure and photosynthesis in the unicellular model Micrasterias. J. Plant Physiol. 169, 1489, 2012.

32. LÓPEZ-CLIMENT M.F., ARBONA V., PÉREZCLEMENTE R.M., ZANDALINAS S.I., GÓMEZCADENAS A. Effect of cadmium and calcium treatments on phytochelatin and glutathione levels in citrus plants. Plant Biology. 16, 79, 2014.

33. LI P., ZHAO C.Z., ZHANG Y.Q., WANG X.M., WANG X.Y., WANG J.F., WANG F., BI Y.R. Calcium alleviates cadmium-induced inhibition on root growth by maintaining auxin homeostasis in Arabidopsis seedlings. Protoplasma. 253, 185, 2016.

34. HAYAT S., AHMAD A., WANI A.S., ALYEMENI M.N., AHMAD A. Regulation of Growth and Photosynthetic Parameters by Salicylic Acid and Calcium in Brassica juncea under Cadmium Stress. Z. Naturforsch. C. 69, 452, 2014.

35. EL-BEITAGI H.S., MOHAMED H.I. Alleviation of Cadmium Toxicity in Pisum sativum L. Seedlings by Calcium Chloride. Not. Bot. Horti. Agrobo. 41, 157, 2013.

36. NELSON M.T. Interactions of divalent cations with single calcium channels from rat brain synaptosomes. J. Gen. Physiol. 87, 201, 1986.

37. JIANG X.J., LUO Y.M., LUO Q., LIU S.L., ZHAO Q.G. Effect of cadmium onnutrient uptake and translocation by Indian Mustard. Environ. Geochem. Hlth. 26, 319, 2004.

38. BRUNE A., DIETZ K.J. A comparative analysis of element composition of roots and leaves of barley seedlings grown in the presence of toxic cadmium, molybdenum, nickel, and zinc concentrations. J. Plant Nutr. 18, 853, 1995.

39. HAYAKAWA N.,TOMIOKA R.,TAKENAKA C. Effects of calcium on cadmium uptake and transport in the tree species Gamblea innovans. Soil Sci. Plant Nutr. 557, 691, 2011.

40. ELLER F., BRIX H. Influence of low calcium availability on cadmium uptake and translocation in a fast-growing shrub and a metal-accumulating herb. Aob. Plants. 8, 2016.

41. GONG X.M., LIU Y.G., HUANG D.L., ZENG G.M., LIU S.B., TANG H., ZHOU L., HU X., ZHOU Y.Y., TAN X.F. Effects of exogenous calcium and spermidine on cadmium stress moderation and metal accumulation in Boehmeria nivea (L.) Gaudich. Environ. Sci. Pollut. Res. 23, 8699, 2016.

42. SCHREIBER, L., HARTMANN, K., SKRABS, M., ZEIER, J. Apoplastic barriers in roots: chemical composition of endodermal and hypodermal cell walls. J. Exp. Bot. 50, 1267, 1999.

43. BAXTER I., HOSMANI P.S., RUS A., LAHNER B., BOREVITZ J.O., MUTHUKUMAR B., MICKELBART M.V., SCHREIBER L., FRANKE R.B., SALT D.E. Root suberin forms an extracellular barrier that affects water relations and mineral nutrition in Arabidopsis. Plos Genet. 5, 188, 2009.

44. HANSCH R., MENDEL R.R. Physiological functions of mineral micronutrients $(\mathrm{Cu}, \mathrm{Zn}, \mathrm{Mn}, \mathrm{Fe}, \mathrm{Ni}, \mathrm{Mo}, \mathrm{B}, \mathrm{Cl})$. Curr. Opin. Plant Biol. 12, 259, 2009.

45. LIU J., LI K.Q., XU J.K., LIANG J.S., LU X.L., YANG J.C., YANG J.C., ZHU Q.S. Interaction of $\mathrm{Cd}$ and five mineral nutrients for uptake and accumulation in different rice cultivars and genotypes. Field Crop. Res. 83, 271, 2003.

46. CLEMENS S. Toxic metal accumulation, responses to exposure and mechanisms of tolerance in plants. Biochimie. 88, 1707, 2006.

47. D'ALESSANDRO A., TAAMALLI M., GEVI F., TIMPERIO A.M., L. ZOLLA L., GHNAYA T. Cadmium stress responses in Brassica juncea: hints from proteomics and metabolomics. J. Proteome Res. 12, 4979, 2013.

48. TOYOTA M., SPENCER D., SAWAI-TOYOTA S., WANG J.Q., ZHANG T., KOO A.J., HOWE G.A., GILROY S. Glutamate triggers long-distance, calcium-based plant defense signaling. Science. 361, 1112, 2018. 